\title{
Correction to: China in Africa
}

\section{Madihah Karim, Rabbiya Kamal and Omair Haroon}

\section{Correction to:}

Chapter 10 in: J. Syed, Y.-H. Ying (eds.), China's Belt and Road Initiative in a Global Context, Palgrave Macmillan Asian Business Series https:// doi.org/10.1007/978-3-030-14722-8_10

The original version of this chapter was revised and the Chapter author named Madihah Karim was incorporated as the first author.

The updated versions of the chapters can be found at https://doi.org/10.1007/978-3-030-14722-8_10

(C) The Author(s) 2020 